\title{
Contraversion of Regional Head Authority in the Appointment and Dismissal of State Civil Apparatus in Office with the Perpetuation of the Power of the Regional Head
}

\author{
Syarif Makmur ${ }^{1}$, Herie Saksono ${ }^{2}$ \\ Regional Secretary of East Seram Regency of Maluku ${ }^{1}$ \\ Agency for Research and Development of the Ministry of Home Affairs ${ }^{2}$
}

\{Syarifmakmur123@gmail.com ${ }^{1}$,herie.saksono@gmail.com²\}

\begin{abstract}
Bureaucratic problems arise when the State's civil apparatus is faced with political interests for the infinity of the regional head's power. This condition has been even more potent for a long time because the district head concurrently became a staffing supervisor official. In the process of dismissal and appointment of civil apparatus positions of the State, regional leaders tend to utilize their power and authority rather than considering the competence and professionalism of ASN in the merit system. The implication is that many positions are not under the ASN's competence, serving in undue positions and the tempo of appointments that take advantage of certain political moments and are more nepotism-oriented. How to overcome the bureaucracy messy in the circle of power so that the human resources apparatus's management increasingly encourages local governments' performance? This study is an empirical observation in the spooky district of eastern Maluku. The approach used is a qualitative-explorative method with the support of a literature review. The goal is to describe reality based on the local government bureaucracy's facts and governance while finding the best solution. Through data analysis found decisive political intervention in bureaucracy. There is also a counter version in the appointment and dismissal of ASN positions because it is contrary to the State Civil Apparatus Law. Political interests and the perpetuation of power through the work and clearance of ASN positions are increasingly felt ahead of regional head elections and after the implementation of local elections. Ironically, this condition is declared as the regulation clause that is considered to provide opportunities for the politicization of bureaucracy in the Local Government.
\end{abstract}

Keywords: Contra Version of Power; Officials of Staffing Supervisors; Civil Apparatus of the State and Local Government 


\section{Introduction}

As of August 19, 2020, the State Civil Apparatus Commission (KASN) has recorded 490 cases of ASN neutrality violations in the 2020 regional elections. A total of 372 people have been granted recommendations for sanctions for breaches of neutrality by KASN. However, the PPK sanctions were only carried out to 194 ASN or 52.2 percent of the total offenders. Therefore, KASN urged the regional head as the Staffing Supervisory Officer (PPK) to crack down firmly on ASN, which proved to be impartial during the local elections. KASN has also reported the performance of PPK to the Minister of Home Affairs and Minister of Administrative and Bureaucratic Reform so that PPK that does not immediately give sanctions will have complained to the President.

Moreover, almost $80 \%$ of the regions that will hold local elections in 2020 will be followed by candidates from the incumbent. There increases the likelihood of violations of ASN neutrality in the area. According to the survey results in the field of assessment and development of the Regional system that conducted the Regional Elections The number of complaints of neutrality of ASN KASN in 2018, several factors cause ASN neutrality violations. Factors include weak sanctions, the impartiality of ASN that is still considered commonplace, lack of integrity of ASN to be neutral, intervention from leaders, lack of regulatory understanding of ASN neutrality, motives to obtain or maintain positions, materials, or projects, and family or kinship relationships with candidates. The percentage of these factors can be seen in Figure 2 (Mokhsen, Dwiputrianti, and Muhammad, 2018).

Bureaucracy cannot be separated from politics, and we cannot separate political problems from administrative problems (Etzioni, 1985; Riggs, 1991). Riggs reinforces the argument that people who think that bureaucracy is politically neutral are the same as those in the bureaucracy as powerless apparatus and devoid of self-interest or power. Like rights theory, Guy Peters and John Pierre (2004) presented his idea on civil service politicization. In a fundamental sense, the two men define civil service politicization as the substitution of political criteria for merit-based criteria in selecting, retaining, promoting, rewarding, and disciplining public service members. The same understanding put forward by Peters and Pierre understands the phenomenon of bureaucracy with a political creation and can't be separated from political problems.

It can't be separated from the bureaucratic structure intended as a public service. Here the bureaucracy plays a critical role in determining who gets what of the existing public sector because the authority over the source or sources, both in the form of public goods and services, is allocated and distributed to the public. Simultaneous local elections were held on December 9, 2020. However, various problems are still found, one of which is related to the State Civil Apparatus' neutrality (ASN). It has been widely known that ASN neutrality violations in elections, especially elections, are not new because it has often happened. In the 2020 Election Insecurity Index (IKP), ASN impartiality is at the top of the list, representing 167 districts/cities from 270 regions. There is a strategic issue over the objectivity of ASN in supporting and facilitating election participants.

Meanwhile, the Election Supervisory Board (Bawaslu) and the State Civil Apparatus Commission (KASN) have recorded many violations of ASN neutrality. Some cases of ASN neutrality breaches in elections include ten issues of alleged violations of ASN neutrality in West Java. Violations that occur in the form of approaching or registering with one of the political parties, attending a meeting or benefiting prospective candidates, and making a declaration or socialization as a Prospective Regional Head on billboards. Besides, there were 
17 cases of alleged INVOLVEMENT of ASN in practical politics in Mamuju. That makes Mamuju the area with the highest instances of suspected crucifixion in Indonesia.

The number of cases of violations of ASN neutrality that occurred in the election certainly raises concerns because it can impact ASN performance in the administration. Therefore, this paper is to briefly review the violation of ASN neutrality in elections and its causes. Violations of the State Civil Apparatus (ASN) still occur a lot ahead of the regional elections (Regional Elections) simultaneously to be held on December 9, 2020. This paper is to review the violations of ASN neutrality in simultaneous local elections and their causes. The causes of ASN impartiality include weak sanctions, common assumptions for non-neutrality, lack of integrity of ASN, intervention from leaders, lack of regulatory understanding of ASN neutrality, motives for obtaining or maintaining positions/materials/projects, and kinship relationships. The impartiality of ASN impacts ASN employees' professionalism, which significantly affects the implementation of public services and government administration effectiveness. Discourse on the right to vote ASN to be eliminated in simultaneous elections can consider the Government to anticipate neutrality ASN. DPR RI is expected to encourage the Government to increase supervision on ASN neutrality. Also, the House of Representatives is expected to continue revising the package of political laws such as elections, local elections, and political parties and the correction of ASN legislation by strengthening the regulation on the neutrality of ASN.

Discussions regarding the authority and power of regional heads continue to take place in the provincial bureaucracy. Mutual highlighting between the central authority, provinces, and districts/cities potentially violate the prevailing laws and regulations, and this will never be completed if the paradigm of regional autonomy, decentralization, and centralization in the implementation of local Government is not seated proportionally ( Rasyid: 2000, Koswara: 2001). Regional head position as an official of staffing supervisors as stipulated in the constitution raises pros and cons (Tarmudji, 1994).

On the one hand, the head of the region's authority and power to put the position of the area not as a central tool but on the other hand, the situation was used to perpetuate the power of the regional head (Sudrajat, 2016). The appointment and dismissal of tens and even hundreds of State civil servants (ASN) in the district government environment by the Regent of Jember in November 2020 became a public spotlight and became a national issue. The Regional People's Representative Council (DPRD) of the Jember Regency in the plenary meeting announced the Regent of Jember from office due to violations of the local government law's constitution and the state civil apparatus (ASN) law.

The practice of government bureaucracy explained Miftah Toha (2003) that almost all state communities worldwide consider that government actions carried out through the bureaucratic machine are the best way to create authorization and establish regulations that bind all parties. Government bureaucracy is an institution that can provide a political role in solving political conflicts that arise between people and groups of people. An example of a war that occurs in the split of political parties that are "supported by the ruling regime" to create party instability so that the party's power will be split and divided to support and increase the smooth pace of government policy due to the weakness of the conflicting party.

Violation of the constitution of the Regent of Jember, immediately followed up by the Governor of East Java by issuing an official letter addressed to the Regent of Jember to cancel the decree of the Regent of Jember on the appointment and dismissal of state civil apparatus in the high office of primary, administrator position and executive position in the regional government environment Jember. Although the meeting and release of the State civil apparatus not only occurred in Jember Regency, the issue of Jember was almost evenly 
distributed nationally so that the Minister of Home Affairs Moh. Tito Karnavian, through the Inspectorate General, has called and examined the Regent of Jember. The result of the examination and summons to the Regent of Jember ended with the return of many state civil servants to their original positions and canceled the Regent of Jember on the appointment dismissal in primary high positions, administrative and executive functions. As is the case in Jember Regency, East Java province, the Regent of Seram East Maluku province also conducted the appointment and dismissal of tens and even hundreds of state civil servants in primary high positions, administrative positions, and executive positions that are not following the provisions of the prevailing laws and regulations.

With his official letter, the Governor of Maluku canceled the Regent of eastern Seram's decree concerning the appointment and dismissal of the State civil apparatus from primary high positions, administrative positions, and executive positions. Violations committed by the Regent of Jember and the Regent of eastern Seram because it is contrary to the state civil apparatus law number 5 of 2014, and its derivatives in the form of Government Regulation. Simultaneous regional head elections in 2020 are the main reasons and motives of regional heads, both governors, regents/mayors who participated in the 2020 regional head elections to utilize the state civil apparatus directly into practical politics in the hope that the regional heads can sink the regional elections to perpetuate their power. Civil servants of this country are prohibited from siding with one of the candidate's spouses. The sanctions are hefty following other laws and regulations in which the ASN in question can be dismissed from office or its status as an ASN. Using ASN devices in this election is very effective because facilities, authorities, and budgets are available in each agency where ASN works.

ASN uses this resource to influence, mobilize, and direct the public or voters to choose one of the region's regional head/deputy head candidates. Impartiality of ASN in elections has become a problematic fact to avoid because of the authority of regional directors in appointing, moving, and dismissing ASN, as it is stipulated in the provisions of Law No. 5 of 2014 on State Civil Apparatus, and Law No. 23 of 2014 on Local Government. It is undeniable that a solid authority belongs to a regional head in appointing, transferring, and dismissing ASN in the region. Suppose it does not follow the direction and orders of the head of the area to re-elect or choose a particular candidate's spouse. In that case, the fear and anxiety of the ASN is a common phenomenon in every election event.

The indecisiveness of the election organizers and the sanctions imposed under the prohibition of the law became the main motive of the ASN to play practical politics. The tradition of ASN's impartiality is due to justification and the absence of reprimands and sanctions from authorized officials or regional heads. Sudrajat. et al. mentioned that the rise of legal issues over the involvement of civil servants in practical political activities shows clearly that the legislation in the field of staffing is still not strong enough to prevent violations of the principle of neutrality in the implementation of elections in the region.

The regional head position as a staffing supervisor is the embryo of abuse of power, as zudi. et al. said that more than that, most of the elected regional heads do not have a bureaucratic background, so their knowledge and understanding of the legislation's provisions in staffing is minimal. Moreover, ahead of the implementation of elections as occurred in eastern Seram Regency, the regional head with all his authority and power raised and dismissed the ASN in the structural echelons two and echelon three without going through the mechanisms and procedures as stipulated in the state civil apparatus (ASN) law, and the successful teams of regional elections carried out the appointment and dismissal, and ironically did not involve the provincial secretary as the authorized official. Violations and abuses of the head of this region's authority and power came into the public spotlight in 
Maluku. The Governor of Maluku emphatically rescinded his appointment and the cessation of the ASN. Many high school teachers are appointed in structural positions, whereas the authority to assign and transfer high school teachers to the governor's source. Still, in reality, the Regent of East Seram dares to do that. Courage violates this rule because it perpetuates power.

\section{Methodology}

Observation and direct observation in the field with the collection of data and documents needed obtained the facts that the regional head has made the appointment and dismissal of the position of civil apparatus of the State does not go through procedures and mechanisms and has violated the provisions of law number 5 of 2014 on a civil device of the State. The violation concerns the position's requirements, competency test, managerial ability, educational background, etc. Some ASNs who were appointed to the post ahead of the election were loaded with nepotism. The absence of competency tests as loaded with a position led to some ASNs dismissed that fulfilled the loaded functions and replaced other ASNs that did not have competencies. For example, the Head of Highways' role in the public works office must be filled by ASN with a background in diploma education three or strata one civil engineering. Still, the position is filled by ASN with experience of economics and social scholars.

In tracing the documents of appointment in that position, there are four fundamental mistakes made by the Regent of East Seram contrary to government administrative law and law number 5 of 2014 state civil apparatus, namely: 1) the appointment and dismissal of the ASN is not through the mechanism Meeting consideration body of office and rank ( Baperjakat) whose chairman is the regional secretary, but in the decree of the Regent of East Seram it is mentioned the letter-number Meeting board of consideration of positions and ranks, 2) Appointment of high school teachers ( SMA) did not get the written approval of the Governor of Maluku, 3) there are several civil apparatuses of the State who were dismissed from their positions for no apparent reason ( unknown errors and violations committed by the ASN in question), and 4) there are several ASN that are lowered echelons of their positions for no clear legal reasons. Overall, the violation of authority and abuse of power has a political motive to pervert power.

\section{Result and Discussion}

According to Miftah Toha (2003): Bureaucracy in Indonesia, in this case, the Government, which is often referred to as the officialdom kingdom(officialdom), in essence, flaunts the power that is arranged hierarchically, meaning that there are no other organizations that rival the growing and growing power of the Government. National political conditions influence the growth of bureaucracy. The politics and bureaucracy of Government are both different but inseparable. A political presence in the bureaucracy is inevitable. Therefore it needs political institutions in the bureaucracy. In a government bureaucracy, it is impossible to be dominated by bureaucrats without providing opportunities for the presence of political institutions. The bureaucratic political theory forecasts that the bureaucracy always contacts politics or at a different level under no circumstances. Because on the one hand, bureaucracy becomes an instrument for the Government in implementing policies from the results of political products. 
On the other hand, bureaucracy is a character and behavior with a desire or rational and irrational to hold power in playing its role in performing the office's duties. Government bureaucracy cannot be separated from political processes and activities. Every group of people who form a governmental order can not be detached from this political aspect. As we know it together, politics consists of people acting politically who are politically organized by interest groups and try to influence the Government to take and implement policies and actions that can lift its interests. The community has a vested interest in getting the Government affected. Direct government bureaucracy will always be in contact with interest groups in the community.

Daniarsyah (2015) suggests that along with the dynamics of reform that has been rolling for 20 years and during the furious practice of politics that color the vital role of the legislature that is polarized to pragmatic interests and not ideological polarization, as well as legislator actors who are limited to the authority they have, certainly looking for a way to maintain and develop power that is by cooperating with the bureaucracy. Because bureaucracy is an institution that becomes the State's personification in carrying out a public policy with other meanings have a political aspect of bureaucracy. Then the question arises in this situation or era, which is more dominant politics affects the performance of bureaucracy or bureaucracy that influences politics in making policy. And can the bureaucracy position in political neutrality.

Political dominance is more substantial and vital to the bureaucracy, especially in state budget policymaking. Political pressures on the executive sometimes make a noise in the executive. Nevertheless, bureaucratic politics can play its role as an actor in implementing policies capable of bargaining and cases of internal party conflict. In other cases, the new order bureaucratic regime is robust because it has an executive who has full authority in the Constitution 45. Unlike the current era of presidential or executive power, it has been amended through the amendment of the Constitution 45.4 fundamental things become this discussion, namely 1) the contra version of the power of the regional head, 2) officials of staffing supervisors, 3) civil apparatus of the State and 4) local government. The head of the region's power is very dominant, making this position targeted and in great demand of all country stakeholders. How not the director of the area owns all the potential energy, both in human resources, the field of budget, licensing, and so on (Rasyid, 2001).

Ndraha (2003) mentions that the three subcultures of Government: social subculture, economic subculture, and power subculture, do not run balanced, where the subculture of power (executive, legislative, and judiciary) is very dominant. People in social subcultures (ustadz, kyai, religious leaders, etc.) are vying to become regional heads and members of the house of representatives. It is ironic that many successful entrepreneurs and famous artists are already wealthy but still want to be regional heads. The regional head position, who also served as an official of staffing supervisors, was also in the spotlight, as Zudi et al.. In many cases in Indonesia, regional heads were caught by the corruption eradication commission (KPK) for selling positions in the bureaucracy. Many people have proposed changes to the law so that the official staffing supervisor's part is handed over to the Regional Secretary (SEKDA). Still, this proposal is raw by the legislature because political considerations are less favorable to the party. After all, the regional head is also an extension of the party's hand in the region. This condition until now, the power of the regional director in human resource management is very prominent and very difficult to control by the people and representatives' house. One of the basic principles in implementing the State Civil Apparatus (ASN) direction is neutrality. That is, every ASN employee does not take sides from any form of influence and does not favor anyone's interests. 
This is then strengthened in Article 9 paragraph (2) of Law No. 5 of 2014 concerning State Civil Apparatus, stating that "ASN employees must be free from the influence and intervention of all political groups and parties." In regional head elections (regional elections), the neutrality ASN principle has always been a hot discussion in various circles. This study identified a problem that is about the prohibition of the State Civil Apparatus's impartiality (ASN) in the Election of Regional Heads. The form of supervision conducted by the Election Supervisory Board (Bawaslu) related to the prohibition of the State Civil Apparatus's impartiality in the Election of Regional Heads. This study uses research methods with normative juridical analysis. By using the runway of bureaucratic theory and democratic state theory. As well as identifying with statutory and conceptual approaches. This approach is used in research because it focuses on the description of substance Law No. 5 of 2014 on State Civil Apparatus with the research object, namely ASN. Another highlight related to this regional Government's power is the dichotomy of regional autonomy and regional princes.

There is a presumption, and the assumption that regional autonomy is the right of the son of the region, on the one hand, has the truth, but on the other hand has also damaged the joints of the Unitary State of the Republic of Indonesia, which equates the position of all citizens in political rights or other state rights (Koswara, 2002 and Rasyid:2001). According to Daniarsyah (2015), three things of insecurity when the bureaucracy is involved in politics as follows (1) The emergence of political intervention in the placement of bureaucratic positions. The influx of political interventions can damage the career and recruitment system because it is based on political relations. It should be based on merit and impersonal systems. (2) When a bureaucrat is in politics, it is feared that there is an abuse of authority over financial resources and public facilities used by bureaucrats to support their political affiliations. (3) The involvement of bureaucracy in politics is also feared to make sedation to particular groups, namely, politically comparable groups to the bureaucrats. It is inseparable from the fact that the bureaucracy has authority in allocating and distributing its resources. If this happens, it can reduce bureaucracy from a public institution to a more profitable institution for some groups of people.

\section{Conclusion}

Through data analysis found solid political intervention in the regional bureaucracy. Political concrete intervention ahead of implementing regional head elections (PILKADA) and after this election aims to perpetuate power hoping that a regional head can control ten years. The regional director also made the appointment and dismissal of ASN positions contrary to the State Civil Apparatus Law. The meeting and release of ASNs full of political interests have undermined the bureaucracy's morals and ethics. Ironically, this condition is declared as the regulatory clauses that are considered to provide opportunities for the politicization of bureaucracy in the Local Government.

From the results as mentioned above can be concluded (1) Appointment and dismissal of ASN in office ahead of elections and after elections aimed at perpetuating the power of regional heads, (2) The appointment and dismissal of ASN in office violates many provisions of applicable legislation, to undermine the moral and ethical bureaucracy that upholds the professionalism and competence of ASN, (3) Neutrality of ASN in the region is difficult to do because the position of the regional head is so dominant that it is difficult to control by the public including the provincial people's representative council (DPRD) which has such 
functions, and (4) Regional autonomy and regional princes are still crucial for the implementation of local Government today and in the future.

\section{References}

[1] B. Guy Peters, The Politics of Bureaucracy, 2001, 5th Ed., London: Routledge.

[2] Dedy H, 2013, New Public Management dan Politik Birokrasi dalam Reformasi Birokrasi di Indonesia, Jurnal Administrasi Publik dan pembangunan, vol 4, No.2 JuliDesember 2013.

[3] Dida, Daniarsyah, 2015, BUREAUCRATIC POLITICAL AND NEUTRALITY OF BUREAUCRACY IN INDONESIA, Pascasarjana, Universitas Padjadjaran Bandung

[4] Frederickson, H. Gorge, and Kevin B Smith, 2003, The Public Administration Theory Primer. United Kingdom: Westview Press.

[5] Kacung Marijan, Sistem Politik Indonesia, 2010, Jakarta: Kencana Media Grup,

[6] Mansyur Achmad, 2010, Teori-Teori Mutakhir Administrasi Publik, Yogjakarta : Rangkang Education.

[7] Mustopadidjaja AR, 2003, Pengendalian Birokrasi dalam Politik Penyelenggaran Pemerintahan RI,

[8] Budiarjo, Miriam, 2008, Dasar-Dasar Ilmu Politik, Gramedia Pustaka Utama, Jakarta.

[9] Friedmann, W., 1967, Legal Theory, Fifth Edition, Steven and Sons, New York.

[10] Marbun, B.N, 1996, Kamus Politik, Pustaka Sinar Harapan, Jakarta.

[11] Meer, Fritz M. Van der (eds), 2015, Comparative Civil Service Systems in the 21st Century, Palgrave Macmillan, London.

[12] Rozi, Syafuan, 2006, Zaman Bergerak, Birokrasi Dirombak: Potret Birokrasi dan Politik Di Indonesia, Pustaka Pelajar, Yogyakarta.

[13] Tarmudji, S., 1994, Profesionalitas Aparatur Negara Dalam Meningkatkan Pelayanan Publik, Bina Aksara, Jakarta.

[14] Thoha, Miftah, 2003. Birokrasi dan politik di Indonesia, Jakarta : PT Raja Grafindo Persada

[15] Utomo, Warsito, 2006, Administrasi Publik Baru Indonesia; Perubahan Paradigma dari Administrasi Negara ke Administrasi Publik, Pustaka Pelajar, Yogyakarta.

[16] Zweigert, Konrad and Hein Kotz, 1992, Introduction to Comparative Law, Clarendon Press, Oxford.

[17] Aulawi ,Akhmad, "Penerapan Sistem Merit Dalam Manajemen ASN dan Netralitas ASN dari Unsur Politik Dalam Undang-Undang Aparatur Sipil Negara", Jurnal Rechtvinding, dikases di http://rechtsvinding.bphn.go.id/jurnal_online/DPR\%20P3i\%20Akhmad\%20Aulawi $\% 20 \%$ 2oASN_REV.pdf.

[18] Cik Pegawai Negeri Sipil dalam Pemilukada (Studi di Jawa Tengah)", Padjadjaran Jurnal Ilmu Hukum, Vol. 1, No. 3, Tahun 2014.

[19] HASNati, "Pertautan Kekuasaan Politik dan Negara Hukum", Jurnal Hukum Respublica, Vol. 3 No. 1, Tahun 2003.

[20] Hayat, "Konsep kepemimpinan Dalam Reformasi Birokrasi:Aktualisasi Pemimpin Dalam pelayanan Publik Menuju Good Governance",Jurnal Borneo Administrator, Vol. 10 No. 1 April 2014.

[21] Kadarsih, Setiajeng dan Sudrajat, Tedi, "Analisis Terhadap Hak Pilih TNI dan Polri dalam Pemilihan Umum”, Jurnal Dinamika Hukum, Vol. 11 No. 1 Januari 2011. 
[22] Ramli, Lili, "Masalah Reformasi Birokrasi", Civil Service, Jurnal Kebijakan dan Manajemen PNS, Vol. 11 No. 2, November 2008.

[23] Saleng, Abrar, "Penegakan Hukum dalam Era Reformasi”, Jurnal Hukum Ius Quia Iustum, Vol. 11 No. 25, Januari 2004.

[24] Sudrajat, Tedi dan Karsona, Agus Mulya, "Menyoal Makna Netralitas Pegawai Negeri Sipil dalam Undang-Undang Nomor 5 Tahun 2014 tentang Aparatur Sipil Negara", Jurnal Media Hukum, Vol. 23, No. 1, Tahun 2016.

[25] Svara, James H, "Complexity in Political-Administrative Relations and The Limits of The Dichotomy Concept," Journal of Administrative Theory \& Praxis, Vol. 28 No. 1, 2006.

[26] Tome, Abdul Hamid, "Reformasi Birokrasi Dalam Rangka Mewujudkan Good Governane Ditinjau dari Peraturan Menteri Pemberdayaan Aparatur Negara dan Reformasi Birokrasi Nomor 20 Tahun 2010", Jurnal Hukum Unsrat, Vol. XX No. 3, April-Juni 2012.

[27] Zudi, Mat; Hidayat, Arief; Hardjanto, Untung Sri, "Netralitas Pegawai Negeri Sipil Dalam Pemilihan Kepala Daerah", Diponegoro Law Review, Vol. 1 No. 4, Tahun 2012.

[28] Fakrulloh, Zudan Arif, "Kedudukan Peraturan Daerah Dalam Pelaksanaan Otonomi Daerah dan Pembangunan Substansi Hukum di Daerah", Majalah Hukum Nasional, 2000 .

[29] Hartini, Sri; Kadarsih, Setiajeng dan Sudrajat, Tedi, Kebijakan Netralitas Polik Pegawai Negeri Sipil dalam Pemilukada (Studi di Jawa Tengah), Laporan Penelitian Hibah Bersaing Tahun Kedua 2015, Purwokerto, Fakultas Hukum Universitas Jenderal Soedirman.

[30] Jawa pos, "Celah Netralitas ASN", http://www.jawapos.com/read/2017/01/18/ 103113/celah-netralitas-ASN, diakses 20 Februari 2017.

[31] Merdeka.com, "Menteri Yuddy Ancam Pecat 56 PNS Tak Netral Saat Pilkada", https://www.merdeka.com/Peristiwa/Menteri-Yuddy-Ancam-Pecat-56-PnsTak-Netral-Saat-Pilkada.Html, diakses 10 Juli 2016.

[32] Solo Poss, "Bawaslu: Ketidaknetralan PNS Boyolali Nomor 1 di Indonesia", http://www.solopos.com/2015/12/09/pilkada-boyolali-bawaslu-

ketidaknetralan-pns-boyolali-nomor-1-di-indonesia-669108, diakses 30 Juni 2016.

[33] E. Peraturan Perundang-undangan

[34] Undang-Undang Dasar Negara Republik Indonesia Tahun 1945.

[35] Undang-Undang Nomor 5 Tahun 2014 tentang Aparatur Sipil Negara (Lembaran Negara Republik Indonesia Tahun 2014 Nomor 6, Tambahan Lembaran Negara Republik Indonesia Nomor 5494).

[36] Undang-Undang Nomor 23 Tahun 2014 tentang Pemerintahan Daerah (Lembaran Negara Republik Indonesia Tahun 2014 Nomor 244, Tambahan Lembaran Negara Republik Indonesia Nomor 5587) sebagaimana telah diubah beberapa kali, terakhir dengan Undang-Undang Nomor 9 Tahun 2015 tentang Perubahan Kedua atas UndangUndang Nomor 23 Tahun 2014 tentang Pemerintahan Daerah (Lembaran Negara Republik Indonesia Tahun 2015 Nomor 58, Tambahan Lembaran Negara Republik Indonesia Nomor 5679).

[37] Peraturan Pemerintah Nomor 37 Tahun 2004 tentang Larangan Pegawai Negeri Sipil Menjadi Anggota Partai Politik (Lembaran Negara Republik Indonesia Tahun 2004 Nomor 128, Tambahan Lembaran Negara Republik Indonesia Nomor 4440). 
[38] Peraturan Pemerintah Nomor 53 Tahun 2010 tentang Disiplin Pegawai Negeri Sipil (Lembaran Negara Tahun 2010 Nomor 74, Tambahan Lembaran Negara Nomor 5135). 